\title{
A Novel Measurement of Speed in Early Internationalization of New Ventures
}

\author{
Oguzhan Aygoren $^{1} \&$ C. Arsen Kadakal ${ }^{1}$ \\ ${ }^{1}$ Department of International Trade, Bogazici University, Istanbul, Turkey \\ Correspondence: Oguzhan Aygoren, Department of International Trade, Bogazici University, Istanbul, TR, \\ Turkey. Tel: 90-212-359-4510.
}

Received: June 10, 2018 Accepted: July 6, 2018 Online Published: August 21, 2018

doi:10.5539/ijms.v10n3p1 URL: https://doi.org/10.5539/ijms.v10n3p1

\begin{abstract}
This study offers a novel approach in conceptualizing and measuring the internationalization speed of new ventures. International entrepreneurship literature deals extensively with the internationalization speed of new ventures; yet, there is not an agreed upon conceptualization of speed. Majority of studies operationalize speed as the time it takes from inception to make the first international activity. However, we know from Physics, speed is equal to distance divided by time. So, current perspective in internationalization literature misses the distance dimension. As a main contribution of this study, we calculate speed in terms of distance and time by using CAGE distance framework with gravity model, investigate the antecedents of this new speed calculation for international new ventures and compare results with the traditional speed measure of time only. Results indicate new speed measurement is more reliable and valid.
\end{abstract}

Keywords: internationalization speed, cage distance, international entrepreneurship, international new ventures

\section{Introduction}

In the last two decades; many studies have shown internationalization process of new ventures; yet, still there are some conflicts in the definition of early internationalization speed due to multidisciplinary structure of literature (Cressy, 2006; Jones et al., 2011; Coueurderoy \& Murray, 2014; Nowinski \& Bakinowski, 2012). Many researchers take "time" as the only dimension for measuring speed by taking the period from inception of the firm to the very first international activity into consideration (Hilmersson, 2014; Ramos et al., 2011, Acedo \& Jones, 2007; Zucchella, Palamara \& Denicolai, 2007; Pla-Barber \& Escriba, 2006). This is a limited perspective and time cannot be the only variable in measuring the internationalization speed since from Physics, we know speed is equal to distance divided by time. In addition, international entrepreneurship literature states speed as one of the three core dimensions of internationalization, with extent and scope being the others (Zahra \& George, 2002; Oviatt \& McDougall, 2005; Jones \& Coviello, 2005; Mathews \& Zander, 2007). As a remedy to this problem, we measure early internationalization speed by utilizing CAGE distance scores and analyze the speed concept with a new conceptual approach, which enables to compare different industries by bringing metric units with gravity model (Ghemawat, 2001). Thus, as the main contribution of this study, we argue new measurement allows a more accurate perspective for the speed variable. It also helps to understand the internationalization process of new ventures by analyzing the underlying factors in more depth.

Speed is one of the most important measures of internationalization; yet, there is not enough scholar attention in its operationalization (Chetty, Johanson, \& Martin, 2014). Pursuing international opportunities is a prevalent growth path for many firms. However, it takes years for some firms even to make an export and still fail, whereas some firms seek internationalization from the start. So, measuring speed and identifying its antecedents allow answering questions such as "Why some firms are going abroad faster than others?", and "What are the factors that affect the speed of early internationalization efforts?"

Measuring speed starts with identifying the distance. Yet, distance is not a prominent factor in identifying speed in the literature (Table 1). This is an important factor to focus because many firms and new ventures enter international markets just to fail and learn that it was a culturally distance place although the target country is a close neighbor. For example, Yemek Sepeti is such a startup which failed its first internationalization attempt in Russia. Yemek Sepeti is the largest company in Turkey in terms of food delivery which handles more than 200000 orders daily according to public company records. As an expansion strategy, the company identified Russia as a 
neighbor with attractive market size and market segment characteristics. So, Yemek Sepeti assumed it would be a natural success in Moscow. However, it turned out Russia has a completely different culture in terms of service business and home delivery. If only there was a way to measure the distance between Turkey and Russia, the company could have a better understanding of its strengths and would target a better country for early successful expansion. Urge to decrease time and move fast prevented the firm overseeing the distance from several perspectives. Distance is a complex measure; however, CAGE framework provides meaningful categories to analyze situational factors in terms of cultural, administrative, geographic and economic in both countries. Once the distance is correctly identified, speed can be measured more realistically.

Chetty et al. (2014) presents a study with similar motivations and offer a new conceptualization of speed. Their conceptualization is really helpful and offer new perspectives in understanding speed. Our approach is different than theirs in terms of distance calculation. They take the number of countries entered each year as the internationalization measure and calculate an average measure for the number of countries entered each year. This is not an actual distance measure; yet, they use this as a proxy. They compare the final model with the traditional time to internationalization measure and find the proposed model fits better than the time measure. We follow a similar approach in this study, yet, we argue, country numbers without taking into account the similarities and differences between the host and target country, the distance calculation will be missing. So, we measure distances with CAGE distance framework.

Also, many studies in international entrepreneurship literature are based on developed countries, overlooking emerging countries. Especially these studies focus on U.S. and some developed countries such as Australia, Denmark, UK, etc. (Reuber \& Fischer, 1997; Oviatt \& McDougall 2005; Dimitratos \& Jones, 2005; Ramos, Acedo \& Gonzalez, 2011; Texeira \& Coimbra, 2014). So, we present an emerging country perspective with data collected in Turkey.

In the remaining of the paper, we first present literature review on the internationalization process of the firm, then present our conceptual model. Later we describe methodology, demonstrate results and present discussion and limitations.

\section{Literature Review}

Internationalization process of a firm is divided into two mainstreams which are internationalization process theory-Uppsala model-(Johanson \& Vahlne, 1977) and international entrepreneurship theory a.k.a. International New Venture (INV) theory (Oviatt \& McDougall, 1994). Both streams conceptualize internationalization process with different temporal perspectives. Uppsala model claims that internationalization of a firm is a gradual process which increases international commitment of the firm over time. The theory proposes that ventures need to accumulate experience, skills and capabilities in the current markets before internationalization pace (Johanson \& Vahlne, 1977). Johansson and Vahlne (1990) claim prerequisites of early internationalization as firm with abundant resources, stable foreign conditions and homogeneity with easy access to information in targeted market, similar characteristics home and host markets. In the last few decades; markets have reached more global conditions with market homogenization (Oviatt \& McDougall, 1994), advances in communication, transportation and technology, and increasing trend of global niche markets (Knight \& Cavusgil, 1996). The radical change in market environments has enabled firms' internationalization process faster and earlier than before. In this regard; acquiring information about unique opportunities become easier and scholars argued that Uppsala model is not applicable for young firms (Cavusgil \& Knight, 2015). Meanwhile, Oviatt and McDougall (1994) criticizes incremental approach for being too broad, linear and predictable pattern of simple ordering or sequential. Hence, Oviatt \& McDougall (1994) proposed INV theory that firms can manage operations cross-countries in very early ages. They define INVs as: “An international new venture as a business organization that, from inception, seeks to derive significant competitive advantage from the use of resources and the sale of outputs in multiple countries." Although both schools adopt time related constructs while evaluating the internationalization process, they differ in the temporal perspectives regarding how fast firms embrace the internationalization process.

In order to cover the term of how quickly firm adapts internationalization process, scholars have introduced different concepts such as pace (Vermeulen \& Berkema, 2002), speed (Wagner, 2004), initial-entry (Oviatt \& McDougall, 2005), accelerated (Pla-Barber \& Escriba-Esteve, 2006), rapid (Freeman, Edwards, \& Schroder, 2006), early (Zhang \& Dodgson, 2007), and post-entry (Morgan-Thomas \& Jones, 2009) etc. Among those concepts, speed is the most commonly used one by scholars (Acedo \& Jones, 2007). Also, in this study, we focus on internationalization speed. In the internationalization literature; speed refers to the length of time in which a firm achieves the degree of internationalization (Hilmersson \& Johansson, 2016; Hilmersson, 2014; Jörgensen, 
2014; Casillas \& Acedo, 2013). Another definition made by Schueffel, Baldegger and Amann (2014): "Speed refers to the length of time within which certain target or result is achieved. It thus generally refers to a quotient with an indicator of time in the denominator."

On the other hand, in Physics, speed indicates scalar quantity that object moves per unit of time. Although, definition of internationalization speed has theoretically similarities in definitions of speed in the natural sciences; practically it is not possible to say the same for the measurement of speed in the internationalization literature. If it is delineated as classical speed concept in physics such as distance divided by time, validity of the previous studies which measures speed of internationalization solely with time must be reconsidered (Chetty et al., 2014). This issue is often argued in the internationalization literature (Chetty et al., 2014; Casillas \& Acedo, 2013). As a review of literature, Table 1 presents the list of the studies about the measurement of internationalization speed in the recent studies which are empirically and theoretically proposed.

Table 1. Internationalization speed and related constructs (years between 2000 and 2017)

\begin{tabular}{|c|c|c|c|c|}
\hline Author(s) & Term of the study & $\begin{array}{l}\text { The role of } \\
\text { speed }\end{array}$ & Sample & Measurement \\
\hline $\begin{array}{l}\text { Hilmersson, Johanson, } \\
\text { Lundberg \& Papaioannour } \\
\text { (2017) }\end{array}$ & $\begin{array}{l}\text { Speed of International } \\
\text { expansion (refers to speed of } \\
\text { internationalization) }\end{array}$ & $\begin{array}{l}\text { Dependent } \\
\text { variable }\end{array}$ & $\begin{array}{l}203 \text { Swedish } \\
\text { SMEs }\end{array}$ & $\begin{array}{l}\text { The average number of new markets entered per year } \\
\text { since inception (dividing number of export market by } \\
\text { the time) }\end{array}$ \\
\hline Mohr \& Batsakis (2016) & Internationalization speed & $\begin{array}{l}\text { Independent } \\
\text { variable }\end{array}$ & 110 retailers & $\begin{array}{l}\text { The number of foreign subsidiaries divided by number } \\
\text { of years since first international sales }\end{array}$ \\
\hline Johanson \& Kalinic (2016) & $\begin{array}{l}\text { Internationalization speed } \\
\text { refers to acceleration } \\
\text { deceleration in the rate of } \\
\text { international commitment }\end{array}$ & $\begin{array}{l}\text { Dependent } \\
\text { variable }\end{array}$ & $\begin{array}{l}2 \text { Italian SMEs } \\
\text { case study }\end{array}$ & $\begin{array}{l}\text { Change in international commitment divided by two } \\
\text { milestones in time }\end{array}$ \\
\hline $\begin{array}{l}\text { Schu, Morschett \& Swoboda } \\
(2016)\end{array}$ & Internationalization speed & $\begin{array}{l}\text { Dependent } \\
\text { variable }\end{array}$ & $\begin{array}{l}150 \text { online } \\
\text { retailers }\end{array}$ & The number of days between two consecutive entries \\
\hline $\begin{array}{l}\text { Hilmersson \& Johansson } \\
\text { (2016) }\end{array}$ & Internationalization speed & $\begin{array}{l}\text { Independent } \\
\text { variable }\end{array}$ & $\begin{array}{l}183 \text { Swedish } \\
\text { SMEs }\end{array}$ & $\begin{array}{l}\text { Mean of number of markets exported/time, relationship } \\
\text { between export and total sales/time, proportion of the } \\
\text { firm's asset in abroad/time }\end{array}$ \\
\hline Guldiken (2016) & $\begin{array}{l}\text { Expansion speed of INV and } \\
\text { Internationalization speed }\end{array}$ & $\begin{array}{l}\text { Dependent } \\
\text { variable }\end{array}$ & 81 SMEs & $\begin{array}{l}\text { Number of foreign subsidiaries divided by time } \\
\text { difference between internationalization degree at the } \\
\text { time of IPO until three years }\end{array}$ \\
\hline Lamotte \& Colovic (2015) & Internationalization speed & $\begin{array}{l}\text { Dependent } \\
\text { variable }\end{array}$ & $\begin{array}{l}1660 \text { firms from } \\
29 \text { countries }\end{array}$ & $\begin{array}{l}\text { Used dummy variable it is assigned as } 1 \text { if FSTS ratio at } \\
\text { least } 25 \% \text { realized within } 3 \text { years from firms' inception }\end{array}$ \\
\hline Li, Qian \& Qian (2015) & Speed of Internationalization & $\begin{array}{l}\text { Dependent } \\
\text { variable }\end{array}$ & 683 Chinese firms & $\begin{array}{l}\text { Proxy labeled divided in three groups; high (Born } \\
\text { global), low (Not provide } \% 25 \text { FSTS ratio within the } \\
\text { first three years of operation but it has foreign activity), } \\
\text { nil (no foreign activity) }\end{array}$ \\
\hline $\begin{array}{l}\text { Chetty, Johanson \& Martin } \\
\text { (2014) }\end{array}$ & Speed of internationalization & $\begin{array}{l}\text { Independent } \\
\text { variable }\end{array}$ & 178 Spanish SMEs & $\begin{array}{l}\text { Formative construct of speed which are measured as } \\
\text { speed of learning (repetition and diversity) and speed of } \\
\text { commitment (people, language and investment) }\end{array}$ \\
\hline $\begin{array}{l}\text { Langseth, Dwyer \& Arpa } \\
\text { (2014) }\end{array}$ & Internationalisation speed & $\begin{array}{l}\text { Dependent } \\
\text { variable }\end{array}$ & $\begin{array}{l}8 \text { Nordic and Irish } \\
\text { SMEs }\end{array}$ & Same measurement from Oviatt \& McDougall (2005) \\
\hline Hilmersson (2014) & Speed of internationalisation & $\begin{array}{l}\text { Independent } \\
\text { variable }\end{array}$ & $\begin{array}{l}203 \text { Swedish } \\
\text { SMEs }\end{array}$ & $\begin{array}{l}\text { The number of foreign markets entered divided by } \\
\text { firms' age }\end{array}$ \\
\hline Jörgensen (2014) & Speed of internationalisation & N/A & Conceptual study & $\begin{array}{l}\text { The time elapsed from the foundation of the firm until } \\
\text { first international activity }\end{array}$ \\
\hline Teixeira \& Coimbra (2014) & Speed of Internationalization & $\begin{array}{l}\text { Dependent } \\
\text { variable }\end{array}$ & $\begin{array}{l}111 \text { Portuguese } \\
\text { University } \\
\text { spin-off firms }\end{array}$ & $\begin{array}{l}\text { Proxy labeled that Time lag between the founding of the } \\
\text { firm and the firm's first international operations within } 3 \\
\text { years which denoted as } 1\end{array}$ \\
\hline Mohr \& Batsakis (2014) & Internationalisation speed & $\begin{array}{l}\text { Dependent } \\
\text { variable }\end{array}$ & $\begin{array}{l}144 \text { retailers from } \\
29 \text { countries }\end{array}$ & $\begin{array}{l}\text { Average number of foreign outlets divided by the } \\
\text { number of years since the firm's first international } \\
\text { expansion }\end{array}$ \\
\hline Powell (2014) & Speed of foreign market entry & $\begin{array}{l}\text { Dependent } \\
\text { variable }\end{array}$ & 114 US law firms & $\begin{array}{l}\text { Measured by year of entry and represented as binary } \\
\text { variable (entry in China) }\end{array}$ \\
\hline
\end{tabular}




\begin{tabular}{|c|c|c|c|c|}
\hline $\begin{array}{l}\text { Amoros, Basco \& Romani } \\
\text { (2014) }\end{array}$ & $\begin{array}{l}\text { Speed of internationalization } \\
\text { and pace of } \\
\text { internationalization treaded as } \\
\text { synonyms }\end{array}$ & $\begin{array}{l}\text { Dependent } \\
\text { variable }\end{array}$ & 374 Entrepreneurs & $\begin{array}{l}\text { Denoted as } 1 \text { if firm achieved } 25 \% \text { of total sales from } \\
\text { abroad and it is less than } 42 \text { months old }\end{array}$ \\
\hline $\begin{array}{l}\text { Casillas \& } \\
\text { Moreno-Menendez (2014) }\end{array}$ & $\begin{array}{l}\text { Internationalization speed/ } \\
\text { Speed of entry }\end{array}$ & $\begin{array}{l}\text { Dependent } \\
\text { variable }\end{array}$ & 889 Spanish firms & The number of days between two international entries \\
\hline Zhou \& Wu (2014) & $\begin{array}{l}\text { Earliness of } \\
\text { internationalization }\end{array}$ & $\begin{array}{l}\text { Independent } \\
\text { variable }\end{array}$ & 381 Chinese firms & $\begin{array}{l}\text { The number of years elapsed between inception and } \\
\text { first international activity }\end{array}$ \\
\hline Casillas \& Acedo (2013) & $\begin{array}{l}\text { Speed in the } \\
\text { internationalization process }\end{array}$ & $\begin{array}{l}\text { Distinct } \\
\text { construct, } \\
\text { independent } \\
\text { variable and } \\
\text { dependent } \\
\text { variable }\end{array}$ & Conceptual study & $\begin{array}{l}\text { A quotient between a specific variation and specific unit } \\
\text { of time }\end{array}$ \\
\hline Chen \& Yeh (2012) & Pace of FDI & $\begin{array}{l}\text { Independent } \\
\text { variable }\end{array}$ & $\begin{array}{l}2688 \text { investments } \\
\text { in China from } 731 \\
\text { Taiwanese firms }\end{array}$ & Time between two successful FDI \\
\hline Lin (2012) & Internationalization pace & $\begin{array}{l}\text { Dependent } \\
\text { variable }\end{array}$ & $\begin{array}{l}656 \text { Taiwanese } \\
\text { firms }\end{array}$ & Average number of foreign subsidiaries per year \\
\hline Chang, Jaw \& Chiu (2012) & Internationalization speed & $\begin{array}{l}\text { Moderating } \\
\text { variable }\end{array}$ & 335 US companies & $\begin{array}{l}\text { Number of years from inception to first year of foreign } \\
\text { sales generated }\end{array}$ \\
\hline $\begin{array}{l}\text { Nowinski \& Bakinowska } \\
\text { (2012) }\end{array}$ & Internationalization speed & $\begin{array}{l}\text { Dependent } \\
\text { variable }\end{array}$ & 372 Polish SMEs & $\begin{array}{l}\text { It is binary, } 25 \% \text { of revenues from abroad within three } \\
\text { years of their foundation, if it meets the criteria, denoted } \\
\text { as } 1 .\end{array}$ \\
\hline Polat \& Mutlu (2012) & Internationalization speed & $\begin{array}{l}\text { Independent } \\
\text { variable }\end{array}$ & $\begin{array}{l}103 \text { Turkish } \\
\text { Logistic } \\
\text { companies }\end{array}$ & $\begin{array}{l}\text { The number of years between the foundation of the firm } \\
\text { and year of the first international activity }\end{array}$ \\
\hline Chang \& Rhee (2011) & Speed of FDI expansion & $\begin{array}{l}\text { Independent } \\
\text { variable }\end{array}$ & 276 Korean firms & $\begin{array}{l}\text { Average number of foreign manufacturing subsidiaries } \\
\text { divided by number of years between since first FDI } \\
\text { until year of the study }\end{array}$ \\
\hline Rohilla (2013) & Speed of Internatiınalization & $\begin{array}{l}\text { Independent } \\
\text { variable }\end{array}$ & 381 Chinese firms & $\begin{array}{l}\text { Time lag between the foundation year of the firm and } \\
\text { the year of foreign sale reached } 10 \% \text { of total revenue }\end{array}$ \\
\hline $\begin{array}{l}\text { Prashantham \& Young } \\
(2011)\end{array}$ & Post entry speed & $\begin{array}{l}\text { Dependent } \\
\text { variable }\end{array}$ & Conceptual study & $\begin{array}{l}\text { No explicit measurement but they utilize two elements; } \\
\text { rate of country scope and international commitment }\end{array}$ \\
\hline $\begin{array}{l}\text { Ramos, Acedo \& Gonzales } \\
(2011)\end{array}$ & $\begin{array}{l}\text { Speed of entry refers to } \\
\text { internationalisation speed }\end{array}$ & $\begin{array}{l}\text { Dependent } \\
\text { variable }\end{array}$ & 945 Spanish firms & $\begin{array}{l}\text { Speed is calculated with time elapsed between the } \\
\text { inception of the firm and first export activity }\end{array}$ \\
\hline $\begin{array}{l}\text { Khavul, Perez-Nordtvedt \& } \\
\text { Wood (2010) }\end{array}$ & Speed of Internationalization & $\begin{array}{l}\text { Independent } \\
\text { variable }\end{array}$ & $\begin{array}{l}76 \text { South African, } \\
92 \text { Chinese and } \\
140 \text { Indian INVs }\end{array}$ & Age at the firm had its first international sale \\
\hline $\begin{array}{l}\text { Musteen, Francis \& Datta } \\
\text { (2010) }\end{array}$ & Internationalization speed & $\begin{array}{l}\text { Dependent } \\
\text { variable }\end{array}$ & 155 Czech SMEs & $\begin{array}{l}\text { The amount of elapsed time (in years) between the year } \\
\text { of firm founding and year of its first international } \\
\text { venture }\end{array}$ \\
\hline Kiss \& Danis (2010) & Speed of internationalization & $\begin{array}{l}\text { Dependent } \\
\text { variable }\end{array}$ & Conceptual study & $\begin{array}{l}\text { The years between the founding of the firm and first } \\
\text { international sales }\end{array}$ \\
\hline $\begin{array}{l}\text { Morgan-Thomas \& Jones } \\
\text { (2009) }\end{array}$ & $\begin{array}{l}\text { Speed of international sales } \\
\text { development }\end{array}$ & $\begin{array}{l}\text { Dependent } \\
\text { variable }\end{array}$ & 200 British firms & $\begin{array}{l}\text { Juxtaposing the time span with firms' international } \\
\text { intensity (ratio of total sales to total turnover divided by } \\
\text { time) }\end{array}$ \\
\hline Cieslik \& Kaciak (2009) & Speed of internationalization & Dependent & $\begin{array}{l}18896 \text { Polish firms } \\
\text { / Conceptual study }\end{array}$ & $\begin{array}{l}\text { Time between year of establishment and year of the first } \\
\text { export sale }\end{array}$ \\
\hline $\begin{array}{l}\text { Coeurderoy \& Murray } \\
\text { (2008) }\end{array}$ & $\begin{array}{l}\text { Speed of internationalisation } \\
\text { refers speed of entry }\end{array}$ & $\begin{array}{l}\text { Dependent } \\
\text { variable }\end{array}$ & $\begin{array}{l}134 \text { German and } \\
241 \text { UK firms ( } 945 \\
\text { market entries in } \\
\text { total) }\end{array}$ & $\begin{array}{l}\text { Number of years between firm start-up and entry in } \\
\text { foreign market }\end{array}$ \\
\hline Kiss \& Danis (2008) & Speed of internationalization & $\begin{array}{l}\text { Dependent } \\
\text { variable }\end{array}$ & Conceptual Study & $\begin{array}{l}\text { The difference between year of firm founding and year } \\
\text { of its first international sale }\end{array}$ \\
\hline Acedo \& Jones (2007) & Internationalization speed & $\begin{array}{l}\text { Dependent } \\
\text { variable }\end{array}$ & 104 Spanish SMEs & $\begin{array}{l}\text { The age of the firm at the entry into international market } \\
\text { (Categorized as } 1 \text { to non-exporters, } 2 \text { to first export } \\
\text { older than } 5 \text { years, } 3 \text { to } 5 \text { and less than } 5 \text { ) }\end{array}$ \\
\hline $\begin{array}{l}\text { Weerawardena, Mort, Liesch } \\
\text { \& Knight (2007) }\end{array}$ & $\begin{array}{l}\text { Accelerated } \\
\text { internationalization }\end{array}$ & $\begin{array}{l}\text { Dependent } \\
\text { variable }\end{array}$ & Conceptual Study & Speed is the time to first international activity \\
\hline
\end{tabular}




\begin{tabular}{|c|c|c|c|c|}
\hline Zhou (2007) & $\begin{array}{l}\text { Speed of born-global } \\
\text { internationalization }\end{array}$ & $\begin{array}{l}\text { Dependent } \\
\text { variable }\end{array}$ & 775 Chinese SMEs & $\begin{array}{l}\text { Number of years between the inception of the firm to } \\
\text { the year when it achieved } 20 \% \text { of total sales in foreign } \\
\text { sales }\end{array}$ \\
\hline $\begin{array}{l}\text { Zuchella, Palamar and } \\
\text { Denicloai (2007) }\end{array}$ & Precocity, rapidity and pace & $\begin{array}{l}\text { Dependent } \\
\text { variable }\end{array}$ & 144 Italian SMEs & $\begin{array}{l}\text { The number of years from the firms founding to } \\
\text { international sales }\end{array}$ \\
\hline $\begin{array}{l}\text { Pla-Barber \& Escriba-Esteve } \\
\text { (2006) }\end{array}$ & $\begin{array}{l}\text { Accelerated } \\
\text { internationalization includes } \\
\text { speed, scope and extent }\end{array}$ & $\begin{array}{l}\text { Dependent } \\
\text { variable }\end{array}$ & 271 Spanish SMEs & $\begin{array}{l}\text { The number of years between the foundation of the firm } \\
\text { and the first year of exporting }\end{array}$ \\
\hline Luo, Zhao \& Du (2005) & Internationalization speed & $\begin{array}{l}\text { Dependent } \\
\text { variable }\end{array}$ & $\begin{array}{l}93 \text { US } \\
\text { e-commerce firms }\end{array}$ & $\begin{array}{l}\text { Difference between the year of a firms' inception and } \\
\text { first international expansion activity }\end{array}$ \\
\hline Oviatt \& McDougall (2005) & Internationalization speed & $\begin{array}{l}\text { Dependent } \\
\text { variable }\end{array}$ & Conceptual study & $\begin{array}{l}\text { Three ways; Time from the discovery of an opportunity } \\
\text { and first foreign market entry: (how rapidly firm enters } \\
\text { foreign markets, how rapidly psychic distant market } \\
\text { entered; and how fast are commitments made) }\end{array}$ \\
\hline Wagner (2004) & Internationalization speed & $\begin{array}{l}\text { Independent } \\
\text { variable }\end{array}$ & 83 German firms & $\begin{array}{l}\text { Speed is proxied by the change in degree of } \\
\text { internationalization from } 1993 \text { to } 1997\end{array}$ \\
\hline $\begin{array}{l}\text { Chetty \& Campbell-Hunt } \\
(2004)\end{array}$ & $\begin{array}{l}\text { Pace and time to } \\
\text { internationalization }\end{array}$ & $\begin{array}{l}\text { Dependent } \\
\text { variable }\end{array}$ & $\begin{array}{l}16 \text { New Zealander } \\
\text { firms }\end{array}$ & $\begin{array}{l}\text { International sales to foreign sales ratio divided by time } \\
\text { from inception to first export }\end{array}$ \\
\hline Johnson (2004) & International start-up & $\begin{array}{l}\text { Dependent } \\
\text { variable }\end{array}$ & $\begin{array}{l}106 \text { US and UK } \\
\text { firms }\end{array}$ & $\begin{array}{l}\text { foreign sales equals to } 20 \% \text { of total sales within } 5 \text { years } \\
\text { from the inception }\end{array}$ \\
\hline $\begin{array}{l}\text { Vermeulen \& Barkema } \\
\text { (2002) }\end{array}$ & $\begin{array}{l}\text { Pace and Speed (both are } \\
\text { synonyms) }\end{array}$ & $\begin{array}{l}\text { Moderating } \\
\text { variable }\end{array}$ & $\begin{array}{l}22 \text { Dutch firms } \\
\text { ( } 741 \text { foreign } \\
\text { market entries) }\end{array}$ & Average number of foreign subsidiaries per year \\
\hline $\begin{array}{l}\text { Autio, Sapienza \& Almeida } \\
\text { (2000) }\end{array}$ & $\begin{array}{l}\text { Age at entry refers to time lag } \\
\text { and speed of firms' } \\
\text { international growth }\end{array}$ & $\begin{array}{l}\text { Independent } \\
\text { variable }\end{array}$ & 59 Finnish firms & $\begin{array}{l}\text { Speed is measured as difference in international sales } \\
\text { between } 1992 \text { and } 1997 \text {; age at entry is the time between } \\
\text { foundation of the firm and first international sales }\end{array}$ \\
\hline
\end{tabular}

According to extant literature, most studies lack explicit definitions of the terms and there is no consensus on a standard theory (Knight \& Cavusgil, 2015). For this reason; similar terms in the studies refer to different temporal perspectives of the speed. However, Prashantham and Young (2009) made a clear distinction between initial entry speed (time between inception of a firm and its first international activity) and post entry speed (period between two international activities) lately, but the studies we gathered fall into three different perspectives; first group focuses on period between firm inception and start of the internationalization which is also known as initial entry speed (Li, Qian, \& Qian, 2015; Jörgensen, 2014; Teixeira \& Coimbra, 2014; Chang, Jaw, \& Chiu, 2012; Nowinski $\&$ Bakinowska, 2012 etc.), second one argues about the time lag between two consecutive international activities also known as post-entry speed (Johanson \& Kalinic, 2016; Schu, Morschett, \& Swoboda, 2016; Mohr \& Batsakis, 2014; Casillas \& Moreno-Menendez, 2014; Chen \& Yeh, 2012 etc.), and the last approach studies on average number of markets entered per year, which is also called as foreign expansion speed (rate) in the IB literature (Hilmersson, Johanson, Lundberg, \& Papaioannour, 2017, Hilmersson \& Johanson, 2016; Lin, 2012; Vermeulen $\&$ Berkema, 2002). In this study, we focus on the initial-entry speed for our conceptualization.

\subsection{The Initial-Entry Speed}

The initial entry speed refers to early and rapid internationalization process of a firm which achieves certain degree of international commitment for first market entry abroad in a specific period. The antecedents of early and rapid internationalization of the firm is a prominent field in internationalization literature. Hence; scholars usually elaborate on the drivers that affect early and rapid internationalization, but do not measure the internationalization speed. Most of the articles treat initial entry speed as dependent variable and measure it with time (Li, Quian, \& Quian, 2015; Langseth, Dwyer, \& Arpa, 2014; Jörgensen, 2014; Teixeira \& Coimbra, 2014). On the other hand, studies which employ speed as independent variable, point out relation between early internationalization process and performance rather than its antecedents.

The early and rapid internationalization speed is employed and denoted as a dummy variable regarding the definitions and criteria in the literature which are related with level of international commitment (i.e. extent/ breadth) and time lag between inception of the firm and first international activity. According to literature, ratio of foreign sales to total sales (FSTS) is a common indicator that provides valuable information about level of international commitment of a firm. This ratio differs from 5 percent to 75 percent. Meanwhile, on the temporal perspective, international venture must perform first international activity within certain period since its inception. This period has been varied from 2 years up to 8 years. Most of these cut off points are by the authors themselves characterized as more or less arbitrary. Consequently, there is no consensus on the definition of INV (Chetty \& 
Campell-Hunt, 2004; Madsen, 2013). These arbitrary changing and unclear definitions may fade the validity of prevalent studies. Yet, terms of 25 percent of annual sales abroad in the first three years following the inception of the firm is a generally accepted criteria to define the firm as an international new venture (INV).

\subsection{Research Model}

This study focuses on firm level and individual level antecedents of internationalization speed which is inline with literature (Zuchella et al., 2007; Acedo \& Jones, 2007; Kalinic \& Forza, 2012; Casillas \& Acedo, 2013; Chetty et al., 2014, Teixeira \& Coimbra, 2014). We adapt the conceptual model from Casillas and Acedo (2013) and focus on the firm level and individual level variables as presented in Figure 1. Also, we add technology intensity of the firms as a moderating variable. The reason for that conceptualization is high tech firms are known to internationalize faster than the low tech firms. So, we would like to test this hypothesis as well.

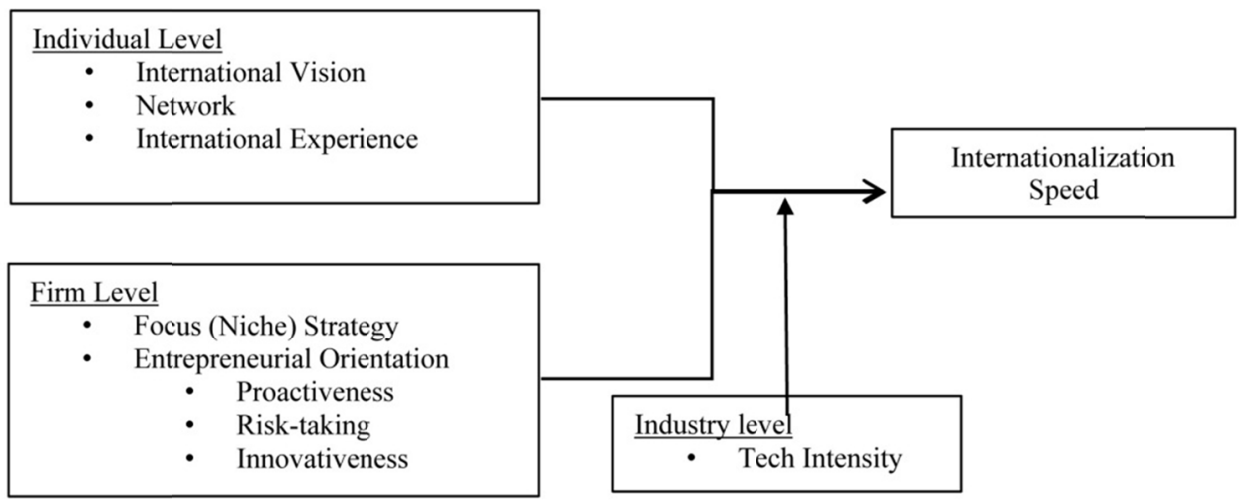

Figure 1. Conceptual model

The entrepreneur has an immense effect on internationalization which is proven by many studies in the literature. What the findings come through early internationalization is highly correlated with entrepreneurs' capabilities such as network, experience and international vision of the firm (Zucchella et al., 2007; Kuemmerle, 2002; Oviatt \& McDougall, 2005). A review of literature also suggests firm level characteristics for internationalization as Entrepreneurial Orientation and focus (niche) strategy of the firm. Firm size is used as a control variable.

Internationalization speed is conceptualized as distance divided by time. Distance is not a commonly used measure in empirical studies in Internationalization literature since it is not easy to quantify the measure. However, CAGE distance framework provides a readily available distance calculation through gravity model (Ghemawat, 2001). The framework includes variables of common official language, colonial linkage, any trade agreement, physcial distance, common border, gdp per capita ratio and product of GDPs and presents the distance in a standardized measure and name it as CAGE distance.

\section{Method}

\subsection{Sampling and Data Collection}

The survey was designed to be answered by the owner of the firm and general managers. The target audience can give a proper answer rather than employees or partners who joined after firm's inception period (Reuber \& Fischer, 1997). Individual-level factors are operationalized from the perspective of the owner of the firm or upper echelon titles of the firm which are managing director and chief executive director. Before the data collection, a pretest was performed with 23 companies via phone. These conversations helped to refine and revise the translated items from original scales.

For the data collection, we have contacted Small and Medium Enterprises Development Organization of Turkey (KOSGEB), and Turkish Exporters Agency (TIM). They agreed to send an email to their firm database with an online survey link. 57790 email invitations were sent during April 2017. Two days later, reminder invitations were sent to the recipients. At the end, we received 632 completed surveys. Responses were investigated to check if they qualify for the INV (International New Venture) definition. The criteria used are as follows:

- NACE code belonging to manufacturing sector part C group 10-33 or Commerce sector part G group 46-47;

- Number of employees less than 250; 
- Established between 2011-2016 (Recent, relatively stable macro economic indicators);

- Having foreign trade activity (except import) within 3 years since its founding;

- Exporter (indirect + direct + ownexporter-no middleman);

- Turkish based firm.

After applying the criteria, remaining sample had 255 firms for the analysis. Characteristics of the firms is presented in Table 2. Also, market entry by region is presented in Table 3. Final sample has $66.67 \%$ of firms with less than 10 employees, $26.83 \%$ with employees between 10 and 49 and only $4.71 \%$ with more than 49 employees. Also, $72.94 \%$ of firms are manufacture firms and $27.06 \%$ of firms are distributive trade firms.

Table 2. Firm characteristics in the sample

\begin{tabular}{|c|c|c|c|c|c|c|c|c|c|c|c|c|c|c|c|}
\hline \multirow{2}{*}{\multicolumn{2}{|c|}{$\begin{array}{l}\text { Firm Established at } \\
\text { Firm Characteristic }\end{array}$}} & \multicolumn{2}{|l|}{2011} & \multicolumn{2}{|l|}{2012} & \multicolumn{2}{|l|}{2013} & \multicolumn{2}{|l|}{2014} & \multicolumn{2}{|l|}{2015} & \multicolumn{2}{|l|}{2016} & \multicolumn{2}{|l|}{ Total } \\
\hline & & Freq. & $\%$ & Freq. & $\%$ & Freq. & $\%$ & Freq. & $\%$ & Freq. & $\%$ & Freq. & $\%$ & Freq. & $\%$ \\
\hline Technology & Low & 17 & $9.8 \%$ & 29 & $16.7 \%$ & 30 & $17.2 \%$ & 36 & $20.7 \%$ & 33 & $19.0 \%$ & 29 & $16.7 \%$ & 174 & $68.24 \%$ \\
\hline Intensity & High & 15 & $18.5 \%$ & 8 & $9.9 \%$ & 13 & $16.0 \%$ & 13 & $16.0 \%$ & 18 & $22.2 \%$ & 14 & $17.3 \%$ & 81 & $31.76 \%$ \\
\hline \multirow[t]{8}{*}{ Region } & Aegean & 3 & $8.6 \%$ & 5 & $14.3 \%$ & 7 & $20.0 \%$ & 7 & $20.0 \%$ & 4 & $11.4 \%$ & 9 & $25.7 \%$ & 35 & $13.73 \%$ \\
\hline & Black Sea & 0 & $0.0 \%$ & 1 & $14.3 \%$ & 1 & $14.3 \%$ & 1 & $14.3 \%$ & 1 & $14.3 \%$ & 3 & $42.9 \%$ & 7 & $2.75 \%$ \\
\hline & Central Anatolia & 5 & $15.6 \%$ & 3 & $9.4 \%$ & 6 & $18.8 \%$ & 4 & $12.5 \%$ & 12 & $37.5 \%$ & 2 & $6.3 \%$ & 32 & $12.55 \%$ \\
\hline & Eastern Anatolia & 0 & $0.0 \%$ & 0 & $0.0 \%$ & 0 & $0.0 \%$ & 1 & $100.0 \%$ & 0 & $0.0 \%$ & 0 & $0.0 \%$ & 1 & $0.39 \%$ \\
\hline & Marmara & 23 & $14.7 \%$ & 25 & $16.0 \%$ & 26 & $16.7 \%$ & 30 & $19.2 \%$ & 28 & $17.9 \%$ & 24 & $15.4 \%$ & 156 & $61.18 \%$ \\
\hline & Mediterranean & 1 & $5.3 \%$ & 1 & $5.3 \%$ & 2 & $10.5 \%$ & 6 & $31.6 \%$ & 6 & $31.6 \%$ & 3 & $15.8 \%$ & 19 & $7.45 \%$ \\
\hline & Southeastern & 0 & $0.0 \%$ & 2 & $40.0 \%$ & 1 & $20.0 \%$ & 0 & $0.0 \%$ & 0 & $0.0 \%$ & 2 & $40.0 \%$ & 5 & $1.96 \%$ \\
\hline & Anatolia & & & & & & & & & & & & & & \\
\hline \multirow[t]{3}{*}{ Firm Size } & $1-9$ & 14 & $8.2 \%$ & 22 & $12.9 \%$ & 30 & $17.6 \%$ & 33 & $19.4 \%$ & 36 & $21.2 \%$ & 35 & $20.6 \%$ & 170 & $66.67 \%$ \\
\hline & $10-49$ & 15 & $20.5 \%$ & 13 & $17.8 \%$ & 10 & $13.7 \%$ & 13 & $17.8 \%$ & 14 & $19.2 \%$ & 8 & $11.0 \%$ & 73 & $28.63 \%$ \\
\hline & $50-249$ & 3 & $25.0 \%$ & 2 & $16.7 \%$ & 3 & $25.0 \%$ & 3 & $25.0 \%$ & 1 & $8.3 \%$ & 0 & $0.0 \%$ & 12 & $4.71 \%$ \\
\hline \multirow[t]{3}{*}{ NACE } & Distributive & 1 & $1.4 \%$ & 9 & $13.0 \%$ & 17 & $24.6 \%$ & 17 & $24.6 \%$ & 14 & $20.3 \%$ & 11 & $15.9 \%$ & 69 & $27.06 \%$ \\
\hline & Trade & & & & & & & & & & & & & & \\
\hline & Manufacture & 31 & $16.7 \%$ & 28 & $15.1 \%$ & 26 & $14.0 \%$ & 32 & $17.2 \%$ & 37 & $19.9 \%$ & 32 & $17.2 \%$ & 186 & $72.94 \%$ \\
\hline Overall & & 32 & $12.5 \%$ & 37 & $14.5 \%$ & 43 & $16.9 \%$ & 49 & $19.2 \%$ & 51 & $20.0 \%$ & 43 & $16.9 \%$ & 255 & $100 \%$ \\
\hline
\end{tabular}

Table 3. Market entry by region

\begin{tabular}{|c|c|c|c|c|c|c|c|c|c|c|c|c|c|c|c|c|c|}
\hline \multirow{3}{*}{\multicolumn{2}{|c|}{$\begin{array}{l}\text { Market Entry by } \\
\text { Region }\end{array}$}} & \multicolumn{16}{|c|}{ First Entry Year } \\
\hline & & \multicolumn{2}{|l|}{2011} & \multicolumn{2}{|l|}{2012} & \multicolumn{2}{|l|}{2013} & \multicolumn{2}{|l|}{2014} & \multicolumn{2}{|l|}{2015} & \multicolumn{2}{|l|}{2016} & \multicolumn{2}{|l|}{2017} & \multicolumn{2}{|c|}{ Years Total } \\
\hline & & Freq. & $\%$ & Freq. & $\%$ & Freq. & $\%$ & Freq. & $\%$ & Freq. & $\%$ & Freq. & $\%$ & Freq. & $\%$ & Freq. & $\%$ \\
\hline World & Asia & 4 & $9.8 \%$ & 2 & $4.9 \%$ & 7 & $17.1 \%$ & 10 & $24.4 \%$ & 6 & $14.6 \%$ & 12 & $29.3 \%$ & 0 & $0.0 \%$ & 41 & $16.08 \%$ \\
\hline \multirow[t]{18}{*}{ Regions } & Eastern & 0 & $0.0 \%$ & 0 & $0.0 \%$ & 0 & $0.0 \%$ & 0 & $0.0 \%$ & 1 & $50.0 \%$ & 1 & $50.0 \%$ & 0 & $0.0 \%$ & 2 & $0.78 \%$ \\
\hline & Africa & & & & & & & & & & & & & & & & \\
\hline & Europe & 6 & $4.9 \%$ & 12 & $9.8 \%$ & 21 & $17.1 \%$ & 20 & $16.3 \%$ & 22 & $17.9 \%$ & 34 & $27.6 \%$ & 8 & $6.5 \%$ & 123 & $48.24 \%$ \\
\hline & Middle & 0 & $0.0 \%$ & 0 & $0.0 \%$ & 1 & $50.0 \%$ & 0 & $0.0 \%$ & 0 & $0.0 \%$ & 0 & $0.0 \%$ & 1 & $50.0 \%$ & 2 & $0.78 \%$ \\
\hline & Africa & & & & & & & & & & & & & & & & \\
\hline & Middle & 1 & $1.7 \%$ & 5 & $8.5 \%$ & 7 & $11.9 \%$ & 10 & $16.9 \%$ & 15 & $25.4 \%$ & 16 & $27.1 \%$ & 5 & $8.5 \%$ & 59 & $23.14 \%$ \\
\hline & East & & & & & & & & & & & & & & & & \\
\hline & Northern & 0 & $0.0 \%$ & 0 & $0.0 \%$ & 1 & $7.1 \%$ & 3 & $21.4 \%$ & 7 & $50.0 \%$ & 3 & $21.4 \%$ & 0 & $0.0 \%$ & 14 & $5.49 \%$ \\
\hline & Africa & & & & & & & & & & & & & & & & \\
\hline & Northern & 0 & $0.0 \%$ & 0 & $0.0 \%$ & 1 & $16.7 \%$ & 2 & $33.3 \%$ & 1 & $16.7 \%$ & 1 & $16.7 \%$ & 1 & $16.7 \%$ & 6 & $2.35 \%$ \\
\hline & America & & & & & & & & & & & & & & & & \\
\hline & Oceania & 0 & $0.0 \%$ & 1 & $33.3 \%$ & 1 & $33.3 \%$ & 0 & $0.0 \%$ & 0 & $0.0 \%$ & 1 & $33.3 \%$ & 0 & $0.0 \%$ & 3 & $1.18 \%$ \\
\hline & Southern & 0 & $0.0 \%$ & 0 & $0.0 \%$ & 0 & $0.0 \%$ & 0 & $0.0 \%$ & 1 & $50.0 \%$ & 1 & $50.0 \%$ & 0 & $0.0 \%$ & 2 & $0.78 \%$ \\
\hline & America & & & & & & & & & & & & & & & & \\
\hline & Western & 0 & $0.0 \%$ & 0 & $0.0 \%$ & 1 & $33.3 \%$ & 0 & $0.0 \%$ & 0 & $0.0 \%$ & 1 & $33.3 \%$ & 1 & $33.3 \%$ & 3 & $1.18 \%$ \\
\hline & Africa & & & & & & & & & & & & & & & & \\
\hline & Region & 11 & $4.3 \%$ & 20 & $7.8 \%$ & 40 & $15.7 \%$ & 45 & $17.6 \%$ & 53 & $20.8 \%$ & 70 & $27.5 \%$ & 16 & $6.3 \%$ & 255 & $100 \%$ \\
\hline & Total & & & & & & & & & & & & & & & & \\
\hline
\end{tabular}




\subsection{Calculation of Tech Intensity}

Tech intensity is an industry level classification showing the general outlook of the industries based on the overall $\mathrm{R} \& \mathrm{D}$ spending in the specific sector. This approach is widely accepted and studied (Hatzichronoglou, 1997). With recent updates on the ISIC technology revision report 3 published by U.N. (2011), technology intensity of the firms has been divided in to four parts which are named; High, Medium-High, Medium-Low, and Low. Turkey has limited number of high tech firms which perfectly fit in the International Standard Industrial Classification (ISIC) technology classification by OECD (2011). Usually firms are condensed on medium-high, low-medium and low industries in Turkey. Low level of survey participants also makes results incompatible. Thus; classification by technology intensity of industries are divided in two main groups as High and Low-Tech industries.

There is common definition in literature for high-tech firms, most of the scholars adopt R\&D spending of firm as indicator of being high-tech (Andersson \& Kuivalanien, 2014). Raymond \& St-Pierre (2011) studied that high performing SMEs relied on innovation. It shows innovation with great potential brings opportunities to enter new markets (Chetty et al., 2014).

Means of R\&D intensity for each classification class in 12 OECD countries has been given by ISIC Technology Intensity Report Rev3. In $2011 \mathrm{R} \& \mathrm{D}$ intensity has been described as a percentage of direct R\&D spending to gross output (production). Mean of technology intensity rates are 9.3 percent for high, 3.0 for medium- high, 0.8 for medium-low, and 0.3 for low categories. In this study; lower than 1.0 intensity rate has been taken as low-tech companies while higher than 1.0 are taken as high-tech companies. With this aspect, research design will be easier to observe differences among firms because of significant technology difference among industries. Thus, it is claimed high and low-tech firms belong to these sector identities. In order to define the tech intensity of sectors, NACE codes of manufacturing and distributive trade sectors are identified. Firms with NACE codes of 20, 21, 26-30, 32a and 33 are classified as High-Technology Industries whereas firms with numbers 10-19, 22-25, 31, 32b, 46 and 47 are classified as Low-Technology industries (Table 4).

Table 4. Refined technology classification

\begin{tabular}{ll}
\hline NACE Code & Technological Intensity (OECD, 2011) \\
\hline 20,21,26,27,28,29,30,32a*,33 & $\begin{array}{l}\text { High-Technology Industries; (Aircraft and Spacecraft, Pharmaceuticals, Office, Accounting and Computing Machinery, } \\
\text { Chemical excluding pharmaceuticals, Railroad equipment and transport equipment, Machinery and equipment) }\end{array}$ \\
\hline & $\begin{array}{l}\text { Low-Technology Industries; (food products and their preparations; beverages; tobacco products; textile products; wearing } \\
\text { apparels; Leather products; wood products; paper and paper products; publishing; coke and refined petroleum products; }\end{array}$ \\
$10,11,12,13,14,15,16,1718$, & rubber and plastic products; non-metallic mineral products; basic metal products; fabricated metal products; furniture; Other \\
& manufacturing products; wholesales; retails) \\
\hline
\end{tabular}

Note. $32 \mathrm{a}^{*}$ : medical and dental products

$32 \mathrm{~b} *$ : other manufacturing product except medical and dental products

According to this classification, $68.24 \%$ of the firms in the sample is in low-tech intensity sectors and $31.76 \%$ is in high-tech intensity sectors.

\subsection{Calculation of Speed with CAGE Distance Score}

In order to measure speed, we use the data CAGE metric distance score from home country to host country (Ghemawat, 2001). Then we calculate the speed ourselves by placing the variables from survey results in the mentioned formula.

Previous research claims internationalization speed is the time elapsed between establishment and the first international trade activity in another country (Khavul et al., 2010; Jörgensen, 2014) but this one-dimensional speed measurement misses the target country characteristics and thus distance (Zahra et al., 2005). When examining the process of internationalization, it is necessary to evaluate three different dimensions together which are extent, scope and speed (Zahra et al., 2005). Therefore, we develop a new conceptual model by adding those missing dimensions replacing the generally used time-dependent speed concept. Our conceptual view for formula of speed measurement is as follows; 
Avg. Internationalization speed $=$

$$
\frac{\sum_{i=1}^{n}\left(\frac{d_{J_{\mathrm{h}} J_{f} S_{l}}}{t i-t 0} x P_{J_{f}}\right)}{(n *(n+1)) / 2}
$$

$\mathrm{n} \sim$ \# of countries entered (scope)

Ti $\sim$ Date of firms' first international activity

T0 Date of firm's establishment

Jh $\sim$ Home country

Jf $\sim$ Host Country

S1 Firm's Industry

dJhJfS1 'Ghemawat CAGE Distance Score' Industry specific distance from home country to host country

$\mathrm{P} \sim$ Type of entry

PJf $\sim$ Perceived effect of preferred type of entry in host market

As an example of how we calculate this distance, let's assume Turkish based " $X$ " firm conducts business in Textile Industry by manufacturing articles of apparels, their accessories not knitted or crochet (Harmonized system code 62) and it performed first international sales as an export activity to Germany in 32 months. Then, the calculation is as follows:

$\mathrm{n}=1$

$\mathrm{Ti}-\mathrm{T} 0=32$ months

$\mathrm{Jh}=$ Turkey (Home country)

$\mathrm{Jf}=$ Germany (Host Country)

$\mathrm{Sl}=$ Apparel, accessories not knited HS code 62 (Firm’s Industry)

$\mathrm{dJhJPSl}=469$ units (Retrieved from Ghemawat database) as 'Ghemawat CAGE Distance Score' Industry specific distance from home country to host country

$\mathrm{P}=$ Export (Type of entry)

PJf $=1$ due to Export (Perceived effect of preferred type of entry in host market)

So, Average Internationalization speed becomes 14.65 CAGE distance unit / month. We perform this calculation for the first export activity of every firm in the sample by using CAGE distance score from Ghemawat database.

\subsection{Measurement of Scales}

International Vision was measured by seven items as suggested in Felicio et al. (2013). 5-point Likert scale has been used (1 indicating strongly disagree; 7 indicating strongly agree).

Entrepreneurial Orientation has three dimensions of proactiveness, risk-taking and innovativeness. In order to measure those items, original scale of Covin and Slevin (1989) was used with 12 items, 5-point Likert scales.

Experience of the top management team and founders was measured as in Reuber \& Fischer (1997) with three items.

Network was asked as a self-rating measure of number of strong networks and number of weak networks with a 5-point Likert scale (1 indicating none, 5 indicating extremely many).

Results of the Explanatory Factor Analysis with loadings and Cronbach Alpha scores are presented in Table 5.

Descriptive statistics and correlations of the variables in the sample is presented in Table 6 .

Also, Confirmatory Factor Analysis was performed showing model fit (CMIN/DF: $1.541<3.00$; GFI: $0.922>0.9$; CFI: 0.968>0.90; NFI: 0.915>0.90; RMSEA: 0.046<0.05). 
Table 5. Results of explanatory factor analysis and Cronbach's alpha scores

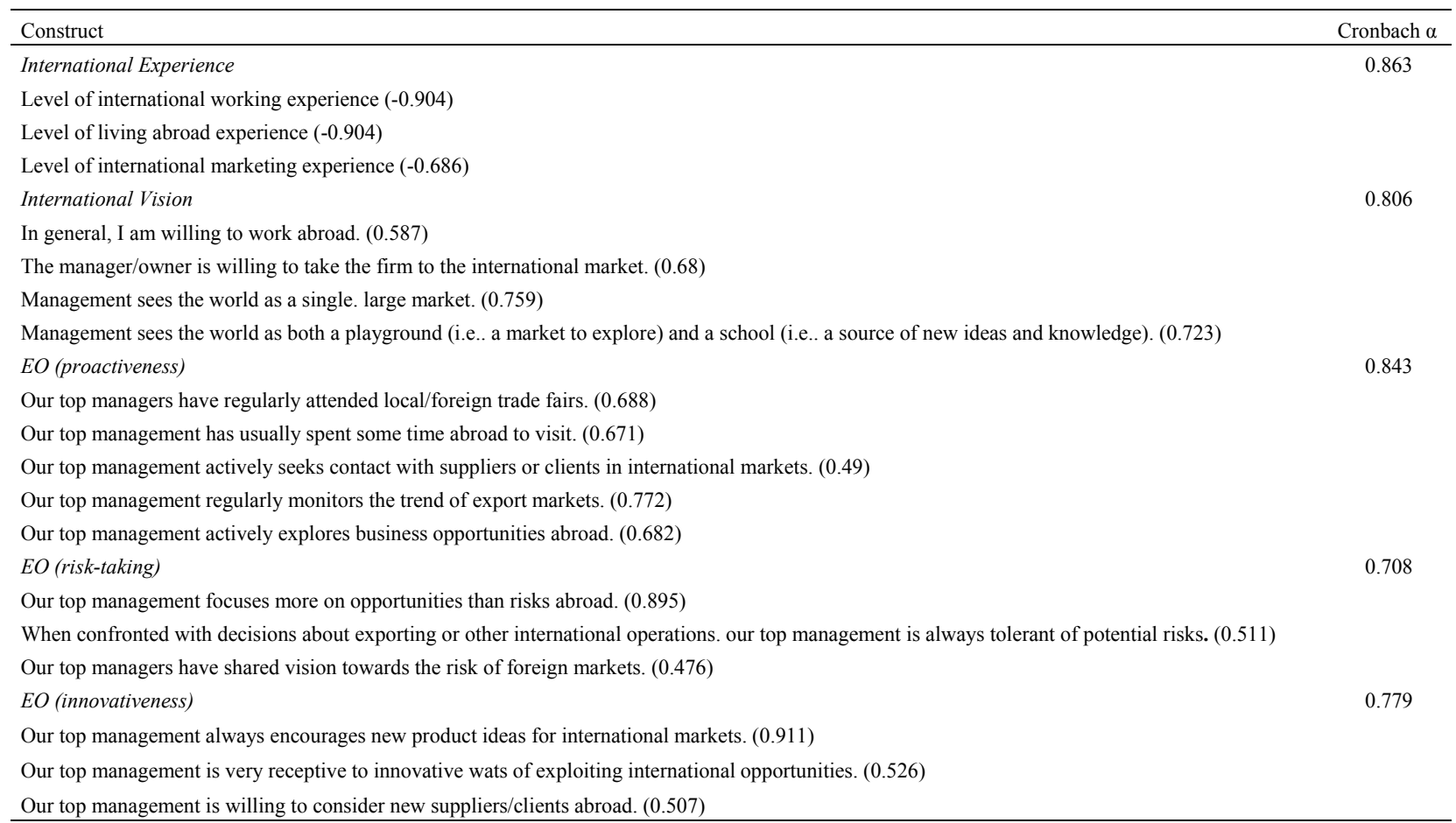

Table 6. Descriptive statistics and correlations of the variables

\begin{tabular}{|c|c|c|c|c|c|c|c|c|c|c|c|c|c|}
\hline & & Mean & $\begin{array}{l}\text { St. } \\
\text { Dev. }\end{array}$ & 1 & 2 & 3 & 4 & 5 & 6 & 7 & 8 & 9 & 10 \\
\hline 1 & $\begin{array}{l}\text { International Speed (in } \\
\text { days) }\end{array}$ & 289.1 & 292.63 & 1 & & & & & & & & & \\
\hline 2 & $\begin{array}{l}\text { Log International Speed } \\
\text { (Distance/time in days) }\end{array}$ & 5.64 & 0.88 & $-.508 * *$ & 1 & & & & & & & & \\
\hline 3 & Network & 3.29 & 1.37 & $.143^{*}$ & $.171^{* *}$ & 1 & & & & & & & \\
\hline 4 & International Experience & 3.24 & 1.18 & $-.252 * *$ & $.296 * *$ & $.367 * *$ & 1 & & & & & & \\
\hline 5 & International Vision & 4.29 & 0.66 & -.051 & $.216^{* *}$ & $.137^{*}$ & $.206^{* *}$ & 1 & & & & & \\
\hline 6 & Proactiveness & 3.74 & 0.82 & $-.171 * *$ & $.195^{* *}$ & $.303 * *$ & $.413 * *$ & $.485^{* *}$ & 1 & & & & \\
\hline 7 & Risk taking & 3.61 & 0.79 & -.075 & 0.094 & 0.092 & $.202 * *$ & $.405^{* *}$ & $.440 * *$ & 1 & & & \\
\hline 8 & Innovativeness & 4.2 & 0.66 & -.093 & $.154^{*}$ & $.220 * *$ & $.262 * *$ & $.550^{* *}$ & $.487 * *$ & $.480^{* *}$ & 1 & & \\
\hline 9 & Focus (Niche) Strategy & 3.92 & 0.96 & -.003 & -.051 & 0.106 & $.160^{*}$ & 0.1 & $.212 * *$ & $.216^{* *}$ & $.215^{* *}$ & 1 & \\
\hline 10 & Firm Size & 1.38 & 0.58 & $.166^{* *}$ & -.122 & 0.072 & .022 & -.01 & 0.1 & -.058 & .028 & 0.064 & 1 \\
\hline
\end{tabular}

Notes. ${ }^{*} \mathrm{p}<0.1 * * \mathrm{p}<0.05$.

\section{Results}

In order to measure the effectiveness of this novel measure of speed proposed in the study, antecedents of internationalization speed were entered into two different regression equations. Model 1 uses Time as the speed variable and Model 2 uses CAGE distance divided by time as the speed variable. In addition, tech intensity of firms were used as moderators. Model 1a and Model 2a show results for firms in low-tech industries whereas Model $1 \mathrm{~b}$ and Model $2 \mathrm{~b}$ show results for firms in high-tech industries. Table 7 presents the results of the regressions. 
Table 7. Standardized coefficient estimates for the regression results of speed

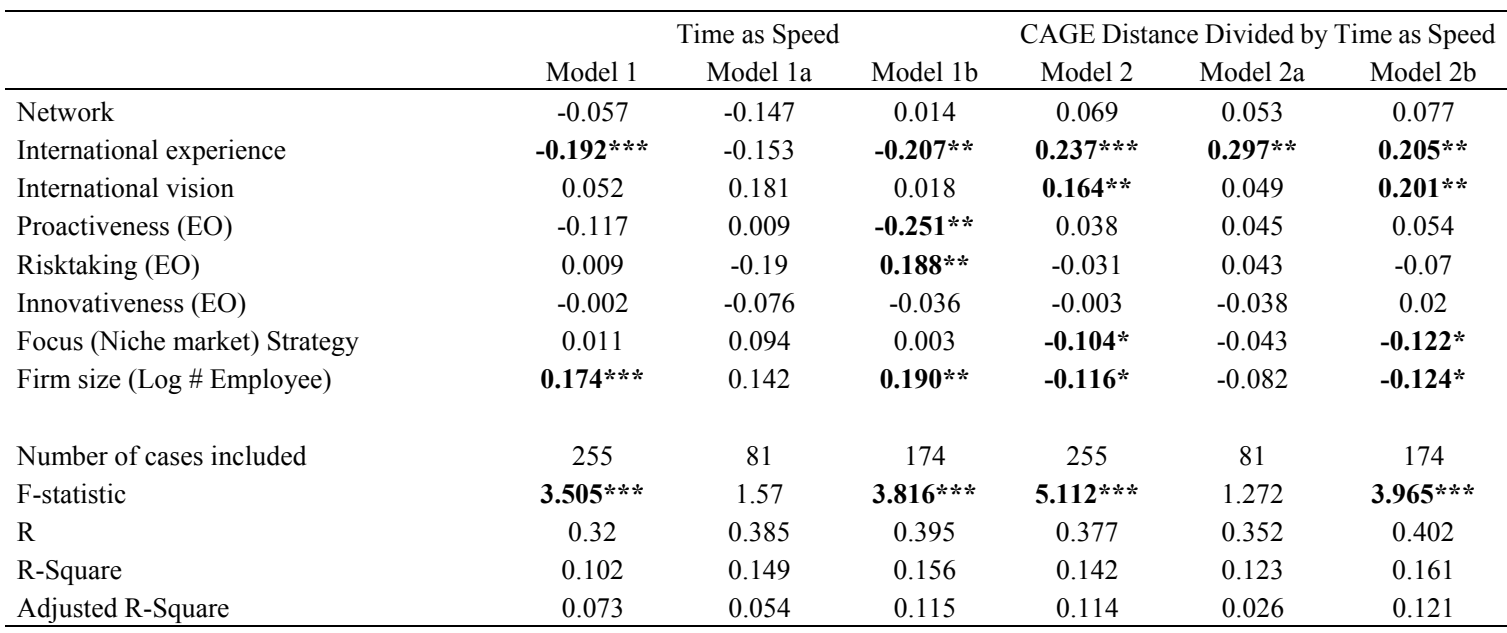

Notes. ${ }^{*} \mathrm{p}<0.1 * * \mathrm{p}<0.05 ; * * * \mathrm{p}<0.01$

Values in bold denotes significant relationship.

Model1: International speed is calculated as time lag in days between the first internationalization and establishment of firm

Model2: International speed is calculated as distance (Ghemawat CAGE distance) / time lag

Model 1 demonstrates, International Experience is a significant factor $(\beta=-0.192, p<0.001)$ affecting the time to first market entry. It is also the most important determinant of internationalization speed. As experience increases, time to enter an international market decreases. Besides, the relationship is valid when it is controlled for firm size. As firm size increases, time to enter a market increases $(\beta=0.174, p<0.001)$.

Model 1a including only the low-tech intensity industries shows there is no significant relationship between the factors and the time as the dependent variable. Model $1 \mathrm{~b}$ on the other hand indicates only the high-tech industries. According to the analysis, International Experience has a negative significant effect $(\beta=-0.207, p<0.05)$ on time and Proactiveness dimension of Entrepreneurial Orientation has a negative significant effect $(\beta=-0.251, p$ $<0.05)$ on time. Risk-taking dimension of Entrepreneurial Orientation has a positive significant effect $(\beta=0.188$, $p<0.05)$ on time. Firm size has a positive significant effect $(\beta=0.190, p<0.05)$ as a control variable.

Model 2 on the other hand shows International Experience is a significant indicator $(\beta=0.237, p<0.001)$ of new speed variable calculated by CAGE Distance divided by time. As international experience increases, the speed of the firm increases in entering a specific market. In addition, International Vision has a positive significant effect $(\beta=0.164, p<0.05)$ on speed. Also, Focus (Niche market) strategy has a negative significant effect $(\beta=-0.116, p<0.1)$ on speed. Firm size has a significant effect $(\beta=-0.116, p<0.1)$ as a control variable.

Model $2 \mathrm{a}$ with only low-tech industries shows International Experience as the only significant variable $\beta=0.297$, $\mathrm{p}<0.05)$. Model $2 \mathrm{~b}$ on the other hand shows similar results with Model 2. International Experience $(\beta=0.205, \mathrm{p}$ $<0.05$ ) and International Vision $\beta=0.201, \mathrm{p}<0.05$ ) have positive significant effects on speed whereas Focus strategy $(\beta=-0.122, p<0.1)$ and firm size $(\beta=-0.124, p<0.1)$ have negative significant effects on speed.

\section{Discussion}

A novel operationalization of speed is used in this study and compared with the standard operationalization of speed as time. Results indicate there are some differences between the significant antecedents of speed though there are some similarities. First of all, International Experience has come as the most important determinant of Internationalization speed. This is inline with literature since learning occurs with the internationalization experience (Chetty et al., 2014). Second, international vision has turned out to be an important determinant of speed when distances are taken into account. This is also an expected finding. Thirdly, as a new finding of this study, firms with focus (niche market) strategy have a lower internationalization speed while focus strategy does not have a significant effect in the traditional measure of speed as time. Fourth, network does not have a significant effect on speed. That is an unexpected finding which is contrary to literature.

Besides, the antecedent of speed, major contribution of this study is our new conceptualization of speed. It can be seen from the analysis that our new conceptualization of speed provides further explanation to internationalization process than the traditional measure of time as internationalization speed. So, the implication of our study is that time to internationalization and speed of internationalization are separate constructs. Firms 
can use this finding in order to analyze their market entry decisions. This is important, because, when firms use time as the only speed variable, the speed variable then ignores which market to enter. However, selecting target markets is an important factor in international market management. Failure to identify the right markets might cause huge costs to firms due to a short sightedness in analyzing the distance between the host country and target country. Firms need to understand and be aware of the distance in order to decide on internationalization speed. So, even if the firm enters two different markets at the same time, speed will be different for firms which will affect the whole internationalization process.

Also, proposed model explains speed better for high tech intensity firms. This is described in the literature with relatively short life cycle of high tech firms (Johnson, 2004) and less-culture specific nature of technology products (Andersson et al., 2014).

\section{Limitations}

One major limitation of the study is internationalization is measured as the first international activity of the company in the equation. So, firms with different entry modes might have a different definition of internationalization. In addition, different definitions of internationalization in the literature are missing. These are post entry speed and average number of markets entered per year. So, this study should be further replicated with various definitions of internationalization.

Another major limitation is the assumptions of CAGE distance framework. Reason to use this framework as distance is it is the only readily available data set for host country to target country distance taking into account various cultural, administrative, geographical and administrative distances. However, this framework might better work for western countries than emerging countries since the Ghemawat distance score includes variables such as colonial linkage. This variable is not relevant for firms in emerging markets such as Turkey. So, new frameworks would be helpful in conceptualizing distance for companies in emerging countries.

Another limitation of the study is due to the characteristics of the sample. When the first internationalization countries are investigated $48 \%$ of the market entries are done to Europe, $23 \%$ to Middle East and $16 \%$ to Asia. Thus, it might be possible that many Turkish firms consider similar markets in their first market entry decisions. This might have led to bias in our analysis. In order to test the effectiveness of CAGE distance framework for using in speed measurement, further studies should include firms from multi-countries leading to multiple host countries and multiple target countries.

\section{Conclusion}

Speed is an important construct in internationalization literature. By truly understanding the factors affecting speed, firms might better select which countries to enter first and which later. Many firms fail at their first internationalization attempt mainly due to wrong calculation of distance or not calculating it at all. Physical proximity of target country is intuitively thought as an important factor when deciding which countries to enter. However, CAGE framework suggests two very close countries might be very far from each other. Conceptualizing speed in terms of distance and time instead of solely focusing on time has major implications in terms of its antecedents. Firms need to be aware of the major differences between time to internationalization and speed of internationalization.

\section{Acknowledgments}

We would like to specifically thank Small and Medium Enterprises Development Organization of Turkey (KOSGEB), and Turkish Exporters Agency (TIM) for aggreeing to cooperate and send emails to companies in their database. Also, we would like to thank to Sema Sakarya for her efforts in the early versions of this study.

\section{References}

Amorós, J. E., Basco, R., \& Romaní, G. (2016). Determinants of early internationalization of new firms: The case of Chile. International Entrepreneurship and Management Journal, 12(1), 283-307. https://doi.org/10.1007/s11365-014-0343-2

Andersson, S., Evers, N., \& Kuivalainen, O. (2014). International new ventures: rapid internationalization across different industry contexts. European Business Review, 26(5), 390-405. https://doi.org/10.1108/EBR-05-2014-0040

Autio, E., Sapienza, H. J., \& Almeida, J. G. (2000). Effects Of Age At Entry, Knowledge Intensity, And Imitability On International Growth. Academy of Management Journal, 43(5), 909-924. https://oi.org/10.2307/1556419 
Casillas, J. C., \& Acedo, F. J. (2013). Speed in the Internationalization Process of the Firm. International Journal of Management Reviews, 15(1), 15-29. https://doi.org/10.1111/j.1468-2370.2012.00331.x

Casillas, J. C., \& Moreno-Menéndez, A. M. (2014). Speed of the internationalization process: The role of diversity and depth in experiential learning. Journal of International Business Studies, 45(1), 85-101.

Cavusgil, S. T., \& Knight, G. (2015). The born global firm: An entrepreneurial and capabilities perspective on early and rapid internationalization. Journal of International Business Studies J Int Bus Stud, 46(1), 3-16. https://doi.org/10.1057/jibs.2014.62

Chang, S. H., Jaw, Y. L., \& Chiu, H. J. (2012). A behavioral perspective of international new ventures: Slack, early internationalization, and performance. Journal of Global Business Management, 8(2), 200. https://doi.org/10.1111/etap.12276

Chang, S. J., \& Rhee, J. H. (2011). Rapid FDI expansion and firm performance. Journal of International Business Studies, 42(8), 979-994.

Chen, C. I., \& Yeh, C. H. (2012). Re-examining location antecedents and pace of foreign direct investment: Evidence from Taiwanese investments in China. Journal of Business Research, 65(8), 1171-1178. https://doi.org/10.1016/j.jbusres.2011.07.032

Chetty, S., \& Campbell-Hunt, C. (2004). A Strategic Approach to Internationalization: A Traditional Versus a "Born-Global" Approach. Journal of International Marketing, 12(1), 57-81. https://doi.org/10.1509/jimk.12.1.57.25651

Chetty, S., Johanson, M., \& Martín, O. M. (2014). The speed of internationalization: Conceptualization, measurement, and validation. Journal of World Business, 49(4), 633-650. https://doi.org/10.1016/j.jwb.2013.12.014

Cieslik, J., \& Kaciak, E. (2009). The Speed Of Internationalization Of Entrepreneurial Start-Ups In A Transition

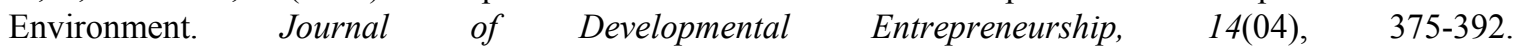
https://doi.org/10.1142/s1084946709001375

Coeurderoy, R., \& Murray, G. (2014). Regulatory Environments and the Location Decision: Evidence from the Early Foreign Market Entries of New-Technology-based Firms. Location of International Business Activities, 226-260. https://doi.org/10.1057/9781137472311_8

Cressy, R. (2006). Why do Most Firms, Die Young? Small Business Economics, 26(2), 103-116. https://doi.org/10.1007/s11187-004-7813-9

Dimitratos, P., \& Jones, M. V. (2005). Future directions for international entrepreneurship research. International Business Review, 14(2), 119-128. https://doi.org/10.1016/j.ibusrev.2004.06.003

Freeman, S., Edwards, R., \& Schroder, B. (2006). How Smaller Born-Global Firms Use Networks and Alliances to Overcome Constraints to Rapid Internationalization. Journal of International Marketing, 14(3), 33-63. https://doi.org/10.1509/jimk.14.3.33

Ghemawat. (2001). Distance Still Matters: The Hard Reality of Global Expansion. Retrieved September 7, 2016, from https://hbr.org/2001/09/distance-still-matters-the-hard-reality-of-global-expansion

Guldiken, O. (2016). Two essays on the internationalization speed of new ventures. Old Dominion University.

Hatzichronoglou, T. (1997). Revision of the High Technology Sector and Product Classification. OECD Science, Technology, and Industry Working Papers, 1997/02, OECD Publishing. https://dx.doi.org/10.1787/134337307632

Hilmersson, M. (2014). Small and medium-sized enterprise internationalisation strategy and performance in times of market turbulence. International Small Business Journal, 32(4), 386-400. https://doi.org/10.1177/0266242613497744

Hilmersson, M., \& Johanson, M. (2016). Speed of SME internationalization and performance. Management International Review, 56(1), 67-94. https://doi.org/10.1007/s11575-015-0257-4

Hilmersson, M., Johanson, M., Lundberg, H., \& Papaioannou, S. (2017). Time, Temporality, and Internationalization: The Relationship Among Point in Time of, Time to, and Speed of International Expansion. Journal of International Marketing, 25(1), 22-45. https://doi.org/10.1509/jim.16.0013

Johanson, J., \& Vahlne, J.-E. (1990). The mechanism of internationalization. International Marketing Review, 7(4), 11-24. https://doi.org/10.1108/02651339010137414 
Johanson, J., \& Vahlne, J-E. (1977). The internationalization process of the firm: A model of knowledge development and increasing foreign market commitments. Journal of International Business Studies, 8(1), 23-32. https://doi.org/10.1057/palgrave.jibs.8490676

Johanson, M., \& Kalinic, I. (2016). Acceleration and Deceleration in the Internationalization Process of the Firm. Management International Review, 56(6), 827-847. https://doi.org/10.1007/s11575-016-0304-9

Johnson, J. E. (2004). Factors influencing the early internationalization of high technology start-ups: US and UK

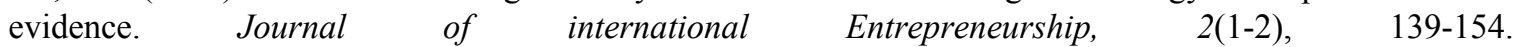
https://doi.org/10.1023/B:JIEN.0000026910.87323.4e

Jones, M. V., \& Coviello, N. E. (2005). Internationalisation: conceptualizing an entrepreneurial process of behavior in time. Journal of International Business Studies, 36(3), 284-303. https://doi.org/10.1057/palgrave.jibs.8400138

Jones, M. V., Coviello, N., \& Tang, Y. K. (2011). International Entrepreneurship research (1989-2009): A domain ontology and thematic analysis. Journal of Business Venturing, 26(6), 632-659. https://doi.org/10.1016/j.jbusvent.2011.04.001

Jørgensen, E. J. (2014). Internationalisation patterns of border firms: speed and embeddedness perspectives. International Marketing Review, 31(4), 438-458. https://doi.org/10.1108/imr-09-2012-0147

Kalinic, I., \& Forza, C. (2012). Rapid internationalization of traditional SMEs: Between gradualist models and born globals. International Business Review, 21(4), 694-707. https://doi.org/10.1016/j.ibusrev.2011.08.002

Khavul, S., Pérez-Nordtvedt, L., \& Wood, E. (2010). Organizational entrainment and international new ventures from emerging markets. Journal of Business Venturing, 25(1), 104-119. https://doi.org/10.1016/j.jbusvent.2009.01.008

Kiss, A. N., \& Danis, W. M. (2008). Country institutional context, social networks, and new venture internationalization speed. European Management Journal, 26(6), 388-399. https://doi.org/10.1016/j.emj.2008.09.001

Kiss, A. N., \& Danis, W. M. (2010). Social networks and speed of new venture internationalization during institutional transition: A conceptual model. Journal of International Entrepreneurship, 8(3), 273-287. https://doi.org/10.1007/s10843-010-0051-0

Knight, G., \& Cavusgil, S. T. (1996). The born global firm: A challenge to traditional internationalization theory. In S. T. Cavusgil \& T. Madsen (Eds), Advances in international marketing (Vol 8, pp. 11-26). Greenwich, CT: JAI Press.

Kuemmerle, W. (2002). Home base and knowledge management in international ventures. Journal of Business Venturing, 17(2), 99-122. https://doi.org/10.1016/s0883-9026(00)00054-9

Langseth, H., O'Dwyer, M., \& Arpa, C. (2016). Forces influencing the speed of internationalisation: An exploratory Norwegian and Irish study. Journal of Small Business and Enterprise Development, 23(1), 122-148. https://doi.org/10.1108/JSBED-10-2013-0155

Li, L., Qian, G., \& Qian, Z. (2015). Speed of internationalization: Mutual effects of individual-and company - level antecedents. Global Strategy Journal, 5(4), 303-320. https://doi.org/10.1002/gsj.1103

Lin, W. T. (2012). Family ownership and internationalization processes: Internationalization pace, internationalization scope, and internationalization rhythm. European Management Journal, 30(1), 47-56. https://doi.org/ 10.1016/j.emj.2011.10.003

Luo, Y., Hongxin Zhao, J., \& Du, J. (2005). The internationalization speed of e-commerce companies: an empirical analysis. International Marketing Review, 22(6), 693-709. https://doi.org/10.1108/02651330510630294

Madsen, T. K. (2013). Early and rapidly internationalizing ventures: Similarities and differences between classifications based on the original international new venture and born global literature. Journal of International Entrepreneurship J Int Entrep, 11(1), 65-79. https://doi.org/10.1007/s10843-012-0099-0

Mathews, J. A., \& Zander, I. (2007). The international entrepreneurial dynamics of accelerated internationalization. Journal of International Business Studies, 38(3), 387-403. https://doi.org/10.1057/palgrave.jibs.8400271 
Mohr, A., \& Batsakis, G. (2014). Intangible assets, international experience and the internationalisation speed of retailers. International Marketing Review, 31(6), 601-620. https://doi.org/10.1108/IMR-09-2013-0186

Morgan-Thomas, A., \& Jones, M. V. (2009). Post-entry Internationalization Dynamics: Differences between SMEs in the Development Speed of their International Sales. International Small Business Journal, 27(1), 71-97. https://doi.org/10.1177/0266242608098347

Musteen, M., Francis, J., \& Datta, D. K. (2010). The influence of international networks on internationalization speed and performance: A study of Czech SMEs. Journal of World Business, 45(3), 197-205. https://doi.org/10.1016/j.jwb.2009.12.003

Nowiński, W., \& Bakinowska, E. (2012). A Logistic Model Study of Endogenous and Exogenous Factors Affecting Polish SMEs' Internationalization Speed. Argumenta Oeconomica, 28, 155-179.

OECD. (2011). OECD Science, "ISIC Revision 3 Technology Intensity Definition", OECD Publishing. https://doi.org/ind/48350231.2011_scoreboard_rev3

Oviatt, B. M., \& Mcdougall, P. P. (1994). Toward a theory of international new ventures. Journal of International Business Studies J Int Bus Stud, 36(1), 29-41. https://doi.org/10.1057/palgrave.jibs.8400128

Oviatt, B. M., \& Mcdougall, P. P. (2005). Defining International Entrepreneurship and Modeling the Speed of Internationalization. Entrepreneurship Theory and Practice Ent. Theory \& Pract, 29(5), 537-554. https://doi.org/10.1111/j.1540-6520.2005.00097.x

Pla-Barber, J., \& Escribá-Esteve, A. (2006). Accelerated internationalization: Evidence from a late investor country. International Marketing Review, 23(3), 255-278. https://doi.org/10.1108/02651330610670442

Polat, I., \& Mutlu, H. M. (2012). The impacts of market orientation, entrepreneurial orientation, environmental uncertainty and internationalization speed on firm performance. European Researcher, (27), 1248-1254.

Powell, K. S. (2014). Profitability and speed of foreign market entry. Management International Review, 54(1), 31-45. https://doi.org/10.1007/s11575-013-0184-1

Prashantham, S., \& Young, S. (2009). Post-Entry Speed of International New Ventures. Entrepreneurship Theory and Practice, 35(2), 275-292. https://doi.org/10.1111/j.1540-6520.2009.00360.x

Ramos, E., Acedo, F. J., \& Gonzalez, M. R. (2011). Internationalisation speed and technological patterns: A panel data study on Spanish SMEs. Technovation, 31(10-11), 560-572. https://doi.org/10.1016/j.technovation.2011.06.008

Reuber, A. R., \& Fischer, E. (1997). The Influence of the Management Team's International Experience on the Internationalization Behaviors of SMEs. Journal of International Business Studies J Int Bus Stud, 28(4), 807-825. https://doi.org/10.1057/palgrave.jibs.8490120

Rohilla, G. (2013). Towards a better understanding of the relationship between speed of internationalization and performance outcomes among young international ventures.

Schu, M., Morschett, D., \& Swoboda, B. (2016). Internationalization speed of online retailers: A resource-based perspective on the influence factors. Management International Review, 56(5), 733-757. https://doi.org/10.1007/s11575-016-0279-6

Schueffel, P., Baldegger, R., \& Amann, W. (2014). Behavioral patterns in born-again global firms: towards a conceptual framework of the internationalization activities of mature SMEs. The Multinational Business Review, 22(4), 418-441. https://doi.org/10.1108/MBR-06-2014-0029

Teixeira, A. A., \& Coimbra, C. (2014). The determinants of the internationalization speed of Portuguese university spin-offs: An empirical investigation. Journal of International Entrepreneurship, 12(3), 270-308. https://doi.org/10.1007/s10843-014-0132-6

Vermeulen, F., \& Barkema, H. (2002). Pace, rhythm, and scope: Process dependence in building a profitable multinational corporation. Strat. Mgmt. J. Strategic Management Journal, 23(7), 637-653. https://doi.org/10.1002/smj.243

Wagner, H. (2004). Internationalization speed and cost efficiency: Evidence from Germany. International Business Review, 13(4), 447-463. https://doi.org/10.1007/s11575-016-0284-9

Weerawardena, J., Mort, G. S., Liesch, P. W., \& Knight, G. (2007). Conceptualizing accelerated internationalization in the born global firm: A dynamic capabilities perspective. Journal of World Business, 42(3), 294-306. https://doi.org/10.1016/j.jwb.2007.04.004 
Zahra, S., \& George, G. (2002). International entrepreneurship: The current status of the field and future research agenda. In M. Hitt, R. D. Ireland, S. M. Camp, \& D. L. Sexton (Eds.), Strategic entrepreneurship (pp. 255 288). Oxford: Blackwell

Zhang, M. Y., \& Dodgson, M. (2007). "A roasted duck can still fly away": A case study of technology, nationality, culture and the rapid and early internationalization of the firm. Journal of World Business, 42(3), 336-349. https://doi.org/10.1016/j.jwb.2007.04.005

Zhou, L., \& Wu, A. (2014). Earliness of internationalization and performance outcomes: Exploring the moderating effects of venture age and international commitment. Journal of World Business, 49(1), 132-142. https://doi.org/10.1016/J.JWB.2013.10.001

Zucchella, A., Palamara, G., \& Denicolai, S. (2007). The drivers of the early internationalization of the firm. Journal of World Business, 42(3), 268-280. https://doi.org/10.1016/j.jwb.2007.04.008

\section{Copyrights}

Copyright for this article is retained by the author, with first publication rights granted to the journal.

This is an open-access article distributed under the terms and conditions of the Creative Commons Attribution license (http://creativecommons.org/licenses/by/4.0/). 